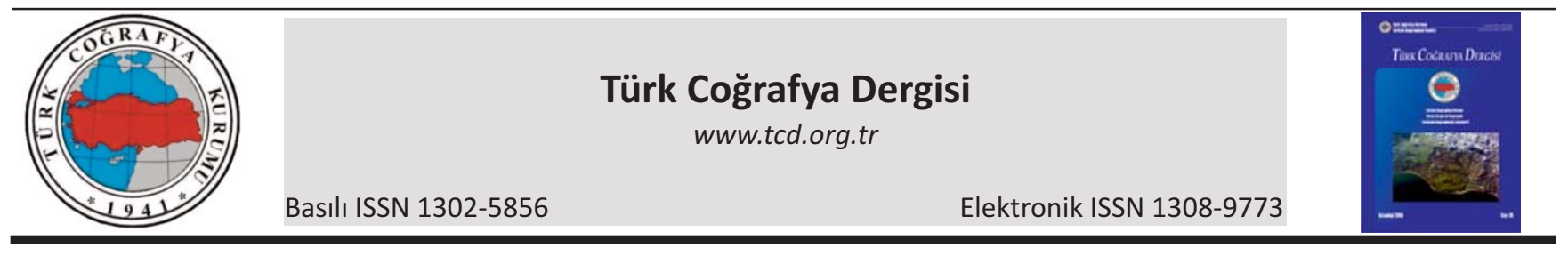

\title{
Bir refah göstergesi olarak Türkiye'de mutluluğun mekânsal dağılışı
}

\author{
Spatial distribution of happiness as a well being indicator in Turkey
}

\author{
Öznur Akgiş*a \\ ${ }^{a}$ Bilecik Şeyh Edebali Üniversitesi, Fen-Edebiyat Fakültesi, Coğrafya Bölümü, Bilecik.
}

\section{MAKALE BILGI}

Geliş/Received: 31.05.2015

Kabul/Accepted: 20.10 .2015

\section{Anahtar Kelimeler:}

Refah

Türkiye

Mutluluk

Kalkınma göstergeleri

Keywords:

Well-being

Turkey

Happiness

Development indicators

*Sorumlu yazar/Corresponding author (Ö. Akgiş) oznur.akgis@bilecik.edu.tr

http://dx.doi.org/10.17211/tcd.91435

\begin{abstract}
ÖZ / ABSTRACT
Geçmişte kalkınma planlarının amacı bireylerin ortalama gelirini arttırmakt. Ancak günümüzde bu geleneksel görüş geçerliliğini yitirmektedir. Maddi olmayan yoksunluklar kalkınma politikalarında giderek daha fazla dikkate alınır olmuştur. Bir toplumun mutluluk düzeyi de bu değişkenlerden biridir. Kalkınma konusundaki çalışmalar insan refahını arttırmayı amaçlar. Bir refah göstergesi olarak mutluluk oranlarının mekânsal dağılışı ise refahı sağlamaya yönelik uygulamalar da hangi bölgelerde yetersizlik yaşandığını gösterir. Ayrıca çözüme yönelik politikalara yön vermesi açısından önem taşır. Bireyin ekonomik ve sosyolojik durumu yaşadığı mekânın sahip olduğu coğrafi özelliklerin avantaj ve dezavantajlar tarafindan şekillenmektedir. Mutluluk soyut bir kavram olmakla birlikte, dağıış deseni değerlendirildiğinde pek çok ülkede mutlu ve mutsuz bireylerin belirli alanlarda yoğunlaştı̆ı görülür. Bu durum soyut olan mutluluk olgusunun, somut olgular tarafindan şekillendirildiğini gösterir. Bu nedenle mutluluk kavramının coğrafi bir bakış açısıyla değerlendirilmesi gerekmektedir. Bu çalışmada da Türkiye'de mutluluk oranlarının dağıışı ve bu dağıış̧a etkili olan coğrafi faktörlerin neler olduğunun tespit edilmesi amaçlanmıştr. Çalışmada kullanılan değişkenler ile mutluluk oranları arasındaki ilişkinin yönünü belirlemek amacıyla korelasyon analizi uygulanmıştı. Yapılan analizler sonucunda kamu kurum ve kuruluşlarının faaliyetlerinden memnuniyet düzeyleri, tarım sektöründe çalışan nüfusun oranı, toplam yaş bağımlılık oranı ile illerin mutluluk düzeyleri arasında pozitif bir ilişki bulunduğu belirlenmiştir. Buna karşın hizmet sektöründe çalışanların oranı, GSYiH, net göç hızı, kadın ve erkek nüfus için ortalama ilk evlenme yaşı, intihar hızı, boşanma ve işsizlik oranları ve lise mezunlarının oranı arasında ise negatif anlamda bir ilişki olduğu tespit edilmiştir.
\end{abstract}

The purpose of development plans was to increase the average income of individuals in the past. However, this traditional view lost its validity now. Intangible deprivations are taken into account gradually in development policy. The happiness ratio of a community is one of these variables. Studies on development aims to improve human welfare. As a welfare indicator spatial distribution of happiness shows where failure occured in the region about applications to ensure well being. Also it has an importance in terms of giving direction to remedial policies. Economic and social status of individuals shaped by advantages and disadvantages of the geographical factors where they live. Happiness is an abstract concept, but when considered together with the distribution pattern is seen in many countries happy and unhappy individuals concentrated in certain areas. This shows that happiness as an abstract fact, shaped by concrete facts. Therefore, the concept of happiness should be considered with geographical perspective. The aim of this study is to determine distribution of happiness and which geographical factors effect this distribution in Turkey. Correlation analysis was performed to determine the direction of the relationship between the variables used in the study with happiness rates. According to results of analysis positive relationship determined between satisfaction level of the activities of public institutions and organizations, proportion of the population working in agriculture, total age dependency ratio, Whereas negative analysis determined between the proportion of employees working on service industry, GDP, net migration rate, average age at first marriage for men and women, suicide rate, divorce and unemployment rates, the percentage of graduates from high school and happiness ratio of provinces.

\section{Giriş}

Geleneksel anlayışa göre kalkınma politikalarında temel amaç kişinin veya hanenin gelirinin arttırılması idi. Çünkü gelir seviyesinde gerçekleşecek artışın tüketimi arttıracağı, bunun da bireyin hayat kalitesini yükselteceği öngörülmekte idi. Ancak bu görüş 1970'lerden itibaren geçerliliğini kaybetmeye başladı (UN, 2005; Ravallion ve Wodon, 1997; Todaro ve Smith, 2012). Kalkınmada amacın, geliri arttırmanın dışında refahın sağlanması olduğu ve gelirin refahı yeterince ifade etmediği anlayışı 
kabul edildi. Elbette bu görüş refah nedir sorusunu akla getirmektedir. Bu konuda kabul edilmiş en yaygın görüş Amartya Sen (1987) tarafindan ortaya atılmıştır. Sen (1987), refah eksikliğinin, yetersiz gelir, eğitim ve sağlık koşullarında, güvenlik sorunlarının olduğu ve politik özgürlüklerin kısıtlandığı ortamlarda ve kişilerin kendine güven konusunda yetersizlikler yaşadığı durumlarda artacağını savunur. Aynı zamanda refahın sağlanmasını, ortalama gelir seviyesinde bir artış yaratma olarak değil halkı doğal afetler ya da salgın hastalıklar gibi muhtemel risklere karşı koruma, yeterli okul sayısını sağlama ya da sağlık hizmetlerinde iyileştirme gibi çalışmalarla desteklenmesi gereken bir süreç olarak görür ve bunu bir çeşit psikolojik durum olarak tanımlar. Onun için refah (well-being), iyi durumda (being well) olmaktır. Bunun belli başlı ölçütleri ise iyi beslenmek, okuryazar olmak, ortalama yaşam süresinin uzunluğu, toplumsal hayata dahil olabilme ve seçim özgürlüğünün bulunmasıdır (Todaro ve Smith, 2012). Burada ifade edilen özgürlük yalnızca siyasi tercihleri değil, bireyin karar verme sürecinde kısıtlamalara neden olan batıl inanç veya kader gibi unsurlardan kendini azat etmesini ifade eder.

Jazairy (1992)'de refah eksikliğinin karar verebilme özgürlüğünün bulunmayışı, sosyal hayata katılımın sınırlı olması ve siyasi anlamda seçim özgürlüğüne sahip olunmamasından kaynaklandığını ifade eder. Doğal afetler, ailede çalışan tek hane halkı üyesinin hayatını kaybetmesi, boşanma, sağlık sorunları ve savaşlar gibi dış etkenlere karşı hassasiyetin yüksek oluşunu kalkınma ve refahı geciktiren unsurlar olarak tanımlar.

Ekonomik anlamda daha yüksek standartlara sahip bir yaşam mı yoksa daha insanca bir yaşam mı sorusu felsefenin en eski sorularındandır. Bu soru değişen çevresel ve sosyal olaylara göre her dönem farklı bir şekilde yanıtlanmaktadır. Çünkü biyolojik olaylarda olduğu gibi toplumsal olaylarda da en kuvvetli etkenlerden biri zamandır. Mutluluk insan refahının en önemli parçalarındandır ancak yüzyıllar boyunca yalnızca felsefenin çaIışma konularından biri olmuştur. Sosyal bilimciler ve ekonomistler tarafindan ise 1950 'lerden sonra ele almaya başlanmıştır (Easterlin, 2001). İnsan refahı gözlenebilen veya doğrudan ölçülebilen bir konu olmamakla birlikte (McGillivray ve Clarke, 2006) çeşitli değişkenler kullanılarak mutluluğun dağılışı ve bu dağılışta etkili olan faktörler konusunda çıkarımlar yapmak mümkündür.

Mutluluk konusunda uzmanlar uzun yıllar boyunca gelir gibi kişiyi tatmin edici unsurlar üzerinde çalışmalar yapmış ve kişinin mutluluk anlayışının ortalama gelire göre değişebileceğini ortaya koymuşlardır (Todaro ve Smith, 2012; Liltsi vd., 2014). Ancak günümüzde bu görüş geçmişte olduğu kadar kabul görmemektedir. Çünkü "fayda" mutluluk olarak tanımlanacak olursa yoksul bireyler daha fazla faydaya sahip olabilecek potansiyele sahiptir. Örneğin, yetersiz beslenmeye maruz kalan bireylerin hayatlarında gerçekleşecek en küçük bir iyileşme bile onlara mutluluk getirebilmektedir. Bu nedenle gelir seviyesi mutluluğu doğrudan etkilemekle birlikte tek başına mutluluk kaynağı olarak tanımlanamaz.

Mutluluk ile ilgili yapılan araştırmalarda gelir dışındaki faktörler giderek daha fazla çalışmaya konu olmaktadır. Layard (2005) ve Kahneman (2003), mutluluğu bireyin hayatından zevk alması ve kendini iyi hissetmesi olarak tanımlamaktadırlar. Brereton vd. (2008)'e göre ise bireyin mutluluğunda çevresel faktörler büyük önem taşır. Çevresel faktörleri konu alan çalışmalar genellikle hava kalitesi (Rehdanz ve Maddison, 2005; Welsch,
2006; 2002; Shapiro, 2006), gürültü kirliliği (Van Praag ve Baarsma, 2005) ve doğal afetler (Ardalan vd., 2011; Calvo vd., 2014) ile ilgilidir. Çevresel faktörlerin dışında ise sosyo ekonomik ve sosyo demografik özellikler ile toplumun mutluluk düzeyini konu alan çok sayıda çalışma bulunmaktadır. Frey ve Stutzer (2002) mutluluğu demografik ve bireysel karakteristiklere göre sınıflandırarak kadınların erkeklere oranla daha mutlu olduğunu ortaya koymuştur. Lucas ve Gohm, (2000)'da kadınların erkeklere oranla daha mutlu olduğunu ifade eder. Cheung ve Chan (2011) ise eğitim seviyesi arttkç̧a mutluluğun da arttığını tespit etmiştir.

Burada belirtilmesi gereken nokta kitlelerin psikolojisini anlamanın onları kontrol etmek olmadığıdır. Le Bon (2014) tarafindan da ifade edildiği üzere kitle psikolojisini anlamaksızın birçok tarihi ve ekonomik olayı harekete geçiren sebeplerin anlaşılması mümkün olmamaktadır. Bu bağlamda günümüzde kalkınma plan ve uygulamalarında maddi olmayan yoksunluklar giderek daha fazla dikkate alınmaktadır. Onuncu Kalkınma Planı'nda da toplumun kendini mutlu hissetmesinin ne derece önem taşıdığı şu şekilde ifade edilmiştir: "Ekonomik amaçların gerçekleştirilmesine paralel olarak Türk vatandaşlarının mutlu, müreffef ve onurlu bir şekilde yaşaması, bu yönde bireylerin kendilerini geliştirebilecekleri, özgür, sağlıklı, güvenli ve yüksek standartta yaşam sürebilecekleri sosyal bir ortamın oluşturulması temel amaçlarımız arasındadır" (Kalkınma Bakanlığı, 2013).

Her ne kadar gelir ve tüketim analizleri küresel kalkınma ve refah çalışmalarının en önemli araçlarından olsa da, gelir seviyesini iyileştirici programların refahı sağlamada yeterli olmadığı açıktır. Artık kalkınmanın esas amacı yalnızca geliri arttırmak değil bireylere daha yaşanılabilir bir çevrede, uzun, sağlıklı ve yaratıcı bir hayat sunmaktır. Ancak bu konuda yapılan çalışmalar oldukça yetersizdir. Bu çalışmada Türkiye'de mutluluğun iller düzeyindeki dağılışı ve sebepleri açıklanmaya çalışılmıştır.

\section{Veri ve yöntem}

Bu çalışma TÜiK tarafindan 2013 yılında yapılan Yaşam Memnuniyeti Araştırması sonucunda elde edilen illere göre mutluluk oranları verilerine dayanmaktadır. Mutluluk düzeyleri ile ilişkisi araştırılan değişkenler, illere göre ortalama hane büyüklüğü, net göç hızı, kadın ve erkek nüfus için ortalama ilk evlenme yaşı, boşanma ve intihar oranları, toplam yaş bağımlılık oranı, bitirilen eğitim düzeyi, kişi başına düşen Gayri Safi Yurtiçi Hasıla (GSYiH), işsizlik oranları ile tarım, sanayi ve hizmet sektöründe çalışan nüfusun toplam nüfus içindeki payıdır. Kamu hizmetlerinden memnuniyet düzeylerinde, sağlık, eğitim, asayiş, ulaşım ve adli hizmetlerden memnuniyet oranları mutluluk ile ilişkisi araştırılan diğer değişkenlerdir (Tablo 1). Bitirilen eğitim düzeyine ilişkin değişkenlerde okur yazar olma durumu iller arasında belirgin farkların olduğu bir değişken olmadığından dikkate alınmamıştır.

Belirlenen değişkenler ile mutluluk düzeyleri arasındaki ilişkinin yönünü belirlemek amacıyla Minitab 16 programı kullanılarak korelasyon analizi yapılmıştır. Ayrıca mutluluk oranlarının illere göre dağılışı ve korelasyon analizi kapsamında değerlendirilen değişkenlerden anlamlılık düzeyi (P-değeri) yüksek olarak belirlenenler ArcGIS 10.0 programı aracılığıyla tematik haritalara dönüştürülmüştür. 
Tablo 1. Korelasyon analizi kapsamında değerlendirmeye alınan değişkenler ( $n=81$ ).

Table 1. Variables evaluated in the context of correlation analysis $(n=81)$.

\begin{tabular}{|c|c|c|c|c|c|}
\hline Değişkenler & Ortalama & $\begin{array}{c}\text { Standart } \\
\text { Sapma }\end{array}$ & Minimum & Maksimum & Kaynak \\
\hline Kişi başına düşen GSYiH & 2143 & 1106 & 688 & 7468 & тÜік, 2001 \\
\hline Ortalama ilk evlenme yaşı (erkek) & 26,5 & 0,888 & 25,00 & 29,3 & тÜí, 2014 \\
\hline Ortalama ilk evlenme yaşı (kadın) & 23,3 & 0,997 & 21,4 & 26,6 & TÜіK, 2014 \\
\hline Sosyal güvenlik kurumlarından memnuniyet oranı (\%) & 69,9 & 11,13 & 34,8 & 89,5 & тÜік, 2013 \\
\hline Sağlık hizmetlerinden memnuniyet oranı (\%) & 77,4 & 7,3 & 54,6 & 89,1 & Tüí, 2013 \\
\hline Eğitim hizmetlerinden memnuniyet oranı (\%) & 74,0 & 8,458 & 48,2 & 88,9 & тüiк, 2013 \\
\hline Adli hizmetlerden memnuniyet oranı (\%) & 55,07 & 13,02 & 28,8 & 84,5 & тÜік, 2013 \\
\hline Asayiş hizmetlerinden memnuniyet oranı (\%) & 84,2 & 7,164 & 58,9 & 94,9 & тüік, 2013 \\
\hline Ulaştırma hizmetlerinden memnuniyet oranı (\%) & 78,2 & 8,791 & 50,20 & 94,2 & Tüí, 2013 \\
\hline İşsizlik oranı (\%) & 8,8 & 3,878 & 4,2 & 23,4 & тüí, 2013 \\
\hline Boşanma hızı (\%) & 1,38 & 0,6436 & 0,11 & 2,87 & тÜік, 2011 \\
\hline Net göç hızı (\%o) & $-3,56$ & 13,25 & $-45,57$ & 42,17 & TÜí, 2014 \\
\hline Tarım sektöründe çalışan nüfusun oranı (\%) & 33,40 & 12,87 & 0,70 & 66,20 & тÜї, 2011 \\
\hline Sanayi sektöründe çalışan nüfusun oranı (\%) & 22,417 & 8,435 & 3,80 & 46,60 & TüiK, 2011 \\
\hline Hizmet sektöründe çalışan nüfusun oranı (\%) & 44,17 & 9,68 & 29,40 & 73,00 & Tüí, 2011 \\
\hline Kaba intihar hızı(\%o) & 4,405 & 1,407 & 0,740 & 9,330 & TüiK, 2014 \\
\hline Ortalama hane büyüklüğü & 5,015 & 1,262 & 3,390 & 8,860 & тÜіK, 2014 \\
\hline Toplam yaş bağımlılık oranı (\%) & 50,93 & 9,56 & 37,34 & 79,81 & тÜіK, 2014 \\
\hline ilkokul mezunu nüfus oranı (\%) & 19,630 & 5,178 & 9,000 & 32,000 & TüiK, 2013 \\
\hline illköğretim mezunu nüfus oranı (\%) & 19,136 & 2,149 & 15,000 & 24,000 & TÜí, 2013 \\
\hline Ortaokul veya dengi okul mezunu nüfus oranı (\%) & 4,284 & 2,129 & 2,000 & 21,000 & TÜIK, 2013 \\
\hline Lise veya dengi okul mezunu nüfus oranı (\%) & 19,654 & 4,539 & 8,000 & 31,000 & тÜіK, 2013 \\
\hline Yüksekokul veya fakülte mezunu nüfus oranı (\%) & 10,346 & 3,046 & 1,000 & 17,000 & Tüí, 2013 \\
\hline
\end{tabular}

\section{Bulgular}

Türkiye İstatistik Kurumu (TÜiK) tarafindan yapılan 2013 yılı Yaşam Memnuniyeti Araştırması sonuçlarına göre, Türkiye nüfusunun \% 59'u mutlu, \% 41'i ise mutsuz olarak belirlenmiştir. Toplam nüfusun neredeyse yarısının kendini mutsuz hissediyor oluşu ülkede refahın sağlanmasında ciddi aksaklıkların yaşandığının bir göstergesidir. En mutlu il Sinop (\% 77,7), en mutsuz il ise Tunceli (\% 42,0)'dir (TÜiK, 2013). Türkiye'de mutluluğun genel dağılışında cinsiyet açısından bir değerlendirme yapılacak olursa kadınların erkeklere oranla daha mutlu olduğu dikkat çeker. Erkeklerde mutluluk oranı \% 56,1 iken kadınların kendini mutlu hissetme oranı \% 61,9'dur. Buna göre mutluluğun hem mekânsal (Şekil 1) hem de cinsiyete göre dağılışında belirgin farklılıklar bulunduğu görülmektedir.

Mutluluğun Türkiye'deki mekânsal dağılışı incelendiğinde (Şekil 1), ülke genelinde olduğu gibi bölgesel anlamda da farklılıklar oldukça belirgindir. Mutluluk oranlarının en düşük olduğu iller Trakya, Akdeniz Bölgesi, Güneydoğu Anadolu Bölgesi ve Doğu Anadolu Bölgesinde yer almaktadır. Mekânsal anlamdaki farkIılaşma birbirine komşu illerde de görülebilmektedir. Sinop en mutlu il iken doğusunda yer alan il olan Samsun en mutsuz iller arasındadır. Aynı şekilde Akdeniz Bölgesinin büyük bölümü mutsuz illerden oluşmakta ilen Kahramanmaraş ve Isparta en mutlu iller olarak bu gruptan ayrılmaktadır. Buna göre mutsuz bireylerin belirli alanlarda yoğunlaşması mutluluk olgusuna coğrafi bir karakteristik kazandırmaktadır. Bu durum mutluluk düzeylerindeki farklılaşmanın sebeplerinin coğrafi unsurlarda aranması gerektiğini göstermektedir.

Analiz sonuçlarına göre ortalama ilk evlenme yaşı ile mutluluk düzeyleri arasında negatif korelasyon bulunmaktadır. Hem erkek hem de kadınlarda ilk evlenme yaşının en yüksek olduğu il Tunceli'dir. Tunceli aynı zamanda en mutsuz ildir. İlk evlilik yaşının erkeklerde en düşük olduğu il Afyonkarahisar'dır ve ilde mutluluk oranı \% 76,4'tür. Kadınlar da ise ilk evlilik yaşının en düşük olduğu il Kırıkkale'dir. Burada ise mutluluk oranı \% 75,5'tir (Şekil 2). Buna göre ortalama ilk evlenme yaşı düştükçe mutluluk düzeyi artmaktadır (Tablo 2).

Ortalama hane büyüklüğü ile mutluluk oranları arasında pozitif korelasyon olduğu belirlenmiştir (Tablo 2). Ancak elde edilen sonuç istatistiksel olarak anlamlı değildir. İllerin mutluluk düzeyleri ile toplam yaş bağımlılık oranları arasında ise pozitif ilişki bulunmaktadır (Tablo 2). Buna göre illerin toplam nüfusu içinde çocuk ve yaşlıların oranı arttıkça mutluluk düzeyleri de artmaktadır. Elazığ ve Muğla illeri toplam yaş bağımlılık oranlarının en düşük olduğu illerdir. Bu iller aynı zamanda mutluluk oranlarının da düşük olduğu alanlara karşılık gelir. Elazığ'da mutluluk oranı \% 51,7, Muğla'da ise \% 52,4'tür. Buna karşın Giresun ve Batman illeri toplam yaş bağımlılık oranlarının fazla olduğu aynı zamanda mutluluk oranlarının da yüksek olduğu illerdir.

Gelir ile ilişkili değişkenler sosyo ekonomik ve coğrafi çalışmaların pek çoğuna konu olmaktadır. Çünkü gelir tek başına bir değişken olmakla birlikte bireylerin tüketim ve tasarruflarını da doğrudan etkiler. Yapılan analizlere göre kişi başına düşen GSYiH ile mutluluk düzeyi arasında negatif korelasyon bulunmaktadır (Tablo 2). Başka bir deyişle gelir artıç̧a mutluluk azalmaktadır. Kişi başına düşen GSYiH değeri en yüksek olan Kocaeli ilinde mutluluk oranı \% 57,2, en düşük olduğu illerden Şırnak'ta ise mutluluk oranı \% 71,4'tür.

Analiz sonuçlarına göre, işsizlik ve mutluluk arasında negatif korelasyon bulunmaktadır (Tablo 2). İşsizlik oranının en fazla olduğu il Batman'dır ve ilin mutluluk oranı \% 52,3'tür. Bu değer oldukça düşüktür. İşsizliğin en az olduğu il ise Karaman'dır. Bu ilde mutluluk oranı ise \% 63'tür. Yine işsizlik oranının düşük olduğu illerden biri olan Uşak'ta da mutluluk oranı \% 72,3'tür (Şekil 4). Buna göre işsizlik mutluluk düzeyini denetleyen önemli bir unsurdur. Analiz sonuçlarına göre işsizlik oranı arttikça mutluluk oranı azalmaktadır.

Nüfusun ekonomik sektörlere göre dağılışı ile de mutluluk düzeyleri arasında da anlamlı bir ilişki olduğu belirlenmiştir. illerin 


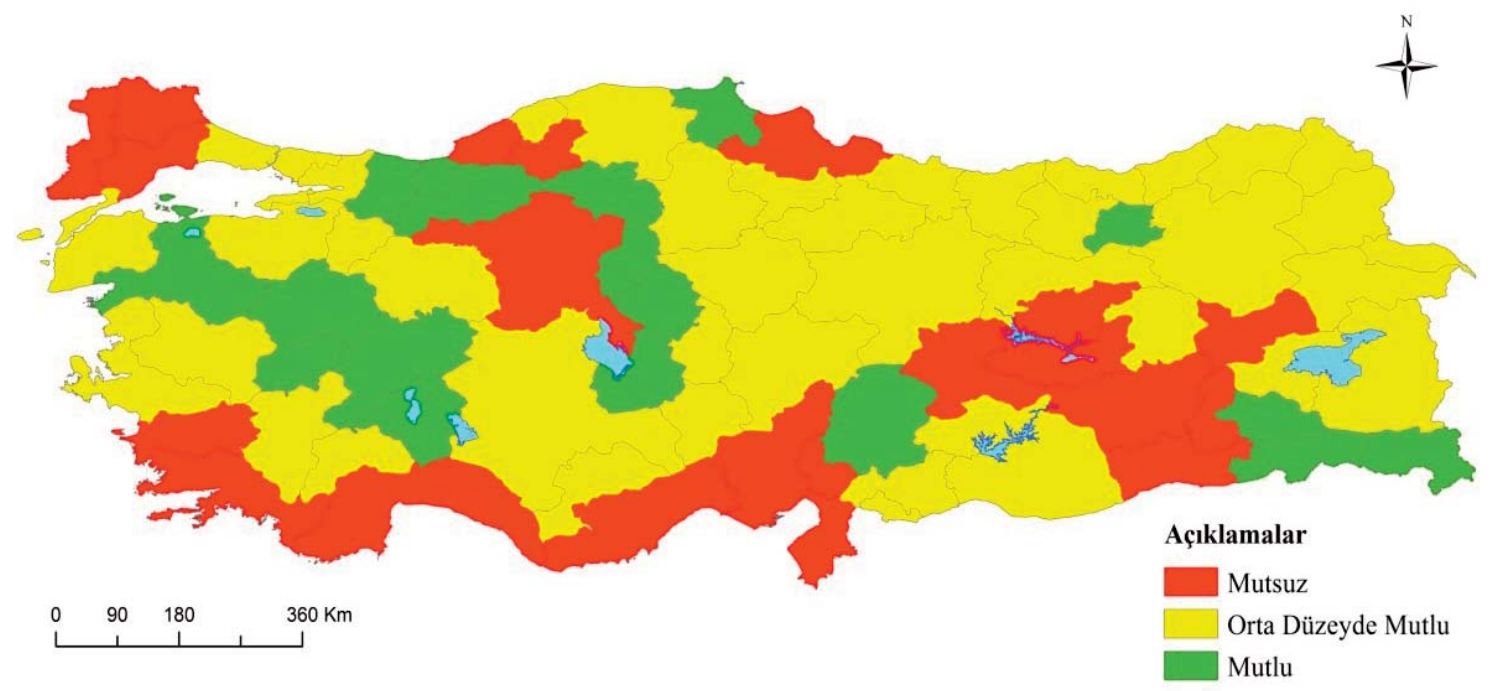

Şekil 1. Mutluluk düzeyinin illere göre dağılışı.

Figure 1. Distribution of happiness level by provinces.

Tablo 2. Mutluluğu etkileyen değişkenlere ilişkin korelasyon analizi sonuçları.

Table 2. Results of correlation analysis related to variables that affect happiness.

\begin{tabular}{lcc}
\hline & & \\
Değişken Adı & $\begin{array}{c}\text { Pearson } \\
\text { Korelasyon } \\
\text { Katsayısı }\end{array}$ & \\
\hline İlk evlenme yaşı (erkek) & $-0,274$ & 0.013 \\
İlk evlenme yaşı (kadın) & $-0,369$ & 0.001 \\
Boşanma hızı (\%) & $-0,031$ & 0.010 \\
Kaba intihar hızı (\%o) & $-0,132$ & 0.024 \\
Sosyal güvenlik hizmetlerinden memnuniyet oranı (\%) & 0.002 \\
Sağlık hizmetlerinden memnuniyet oranı (\%) & 0,345 & 0,000 \\
Eğitim hizmetlerinden memnuniyet oranı (\%) & 0,413 & 0.000 \\
Asayiş hizmetlerinden memnuniyet oranı (\%) & 0,393 & 0.007 \\
Adli hizmetlerden memnuniyet oranı (\%) & 0,298 & 0.004 \\
İşsizlik oranı (\%) & 0,316 & 0.033 \\
GSYì & $-0,238$ & 0.035 \\
Tarım sektöründe çalışan nüfus oranı (\%) & $-0,129$ & 0.046 \\
Sanayi sektöründe çalışan nüfus oranı (\%) & 0,222 & 0.580 \\
Hizmet sektöründe çalışan nüfusun oranı (\%) & $-0,062$ & 0.030 \\
Net göç hızı (\%o) & $-0,241$ & 0.022 \\
Ortalama hane büyüklüğü & $-0,027$ & 0.923 \\
Toplam yaş bağımlılık oranı (\%) & 0,011 & 0.042 \\
Okuryazar olmayan nüfus (\%) & 0,039 & 0.009 \\
İlkokul mezunu nüfus oranı (\%) & 0,009 & 0.008 \\
İlköğretim mezunu nüfus oranı (\%) & 0,017 & 0.093 \\
Ortaokul veya dengi okul mezunu nüfus oranı (\%) & 0.092 \\
Lise veya dengi okul mezunu nüfus oranı (\%) & 0.039 \\
Yüksekokul veya fakülte mezunu nüfus oranı (\%) & 0.053 \\
\hline
\end{tabular}

toplam nüfusu içinde tarım sektöründe çalışanların oranı ile mutluluk oranları arasında pozitif korelasyon bulunmaktadır (Tablo 2). Tarımsal nüfusun fazla olduğu Bayburt, Ardahan, Adıyaman illerinde mutluluk oranları daha yüksek iken, tarımsal nüfusun az olduğu İstanbul, Kocaeli ve Ankara illerinde mutluluk oranları daha düşüktür (Şekil 3). Bir diğer anlamlı sonuç hizmet sektöründe çalışan nüfusa ilişkindir. Burada tarım sektöründe çalışan nüfusun tam aksine mutluluk düzeyleri ile negatif anlamda doğrusal bir ilişki olduğu belirlenmiştir (Tablo 2). Buna göre hizmet sektöründe çalışan nüfus arttkça mutluluk oranı azalmaktadır. Ankara ve Tunceli illeri hizmet sektöründe çalışanların en fazla, mutluluk oranlarınınsa en düşük olduğu illerdir. Bu sektörde çalışan nüfusun en az olduğu illerden Adıyaman'da mutluluk oranı \% 65,0, Uşak'ta ise \% 72,3'tür.
Sanayi sektöründe çalışan nüfus ile mutluluk düzeyleri arasında ise negatif korelasyon olduğu belirlenmiştir. Ancak anlamlılık düzeyine göre (P-değeri) elde edilen sonuç istatistiksel olarak anlamlı değildir.

Kamu hizmetlerinden memnuniyet durumu mutluluk üzerindeki belirleyici değişkenlerdendir. Sosyal güvenlik, eğitim, sağIık, ulaşım, asayiş ve adli hizmetler ile mutluluk düzeyi arasında pozitif korelasyon söz konusudur (Tablo 2). Adli hizmetlerden memnuniyetin en düşük olduğu il \% 28,8 ile Burdur, mutluluk oranı \% 56,8'dir. Eğitim hizmetlerinden memnuniyet durumunun en fazla olduğu il ise Afyonkarahisar'dır (Şekil 5). İl aynı zamanda mutluluk düzeyinin de en yüksek olduğu iller arasındadır. Ülke genelinde kamu hizmetlerinin niteliğinin art- 
masının toplumsal mutluluğu olumlu etkilediği görülmektedir.

Sosyal değişkenler açısından değerlendirildiğinde illerin mutluluk düzeyleri ile boşanma oranları arasında negatif korelasyon tespit edilmiştir (Tablo 2). Buna göre, boşanma oranı azaldıkça mutluluk düzeyi artmaktadır. Boşanma oranı en düşük olduğu il Hakkari, mutluluk oranı \% 70,6 iken boşanma oranı en yüksek olduğu il olan İstanbul'da da oran \% 58,4'tür. İntihar oranları ile mutluluk arasında ise negatif korelasyon söz konusudur (Tablo 2). İntihar olaylarının fazla yaşandığı şehirlerde mutluluk düzeyinin daha düşük olduğunu söylemek mümkündür. İntihar vakalarının en fazla yaşandığı iki il Karaman ve Ardahan'dır. Mutluluk oranları da sırasıyla \% 63,0 ve \% 60,7'dir.

illerin net göç hızları ile mutluluk oranları arasında negatif korelasyon olduğu belirlenmiştir (Tablo 2). Buna göre göç hızı arttıkça mutluluk oranları düşmekte, göç hızı azaldıkça mutluluk oranları artmaktadır. Sonuç olarak mutluluk oranları düşük olan illerin daha fazla göç verdiğini bu nedenle göç olgusunun mutluluk ile ilgili olduğunu söylemek mümkündür.

Eğitim ile ilgili göstergeler kalkınma çalışmalarında en fazla dikkate alınan değişkenlerdendir. Çalışmada eğitim ile ilgili göstergelerden olan bitirilen okul düzeyi dikkate alınmıştır. Korelasyon analizi sonuçlarına göre bu göstergelerden ilköğretim, orta öğretim ve yüksekokul veya fakülte mezunu olan nüfusa ilişkin elde edilen değerler istatistiksel olarak anlamlı bulunmamıştır. Lise ve dengi bir okuldan mezun olanların oranı ile mutluluk düzeyleri arasında ise negatif korelasyon olduğu belirlenmiştir. Buna göre bitirilen okul düzeyi lise olan bireyler toplumun geneline göre daha mutsuzdur.

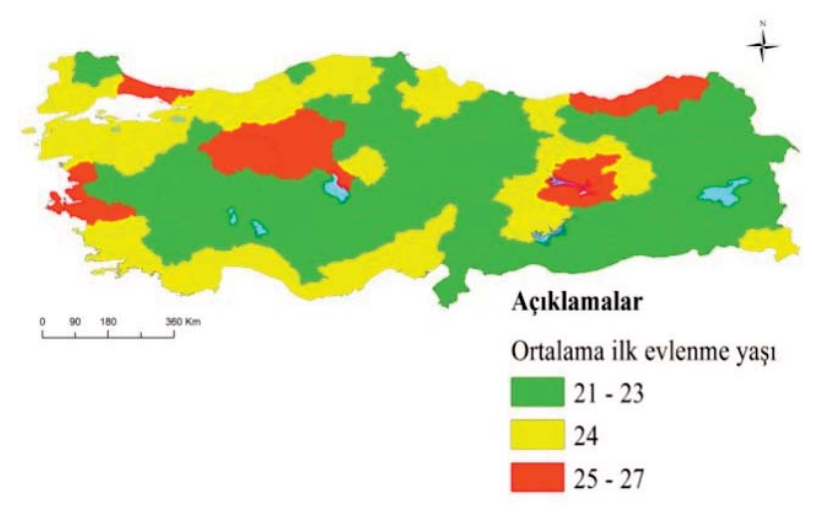

Şekil 2. Ortalama ilk evlenme yaşının illere göre dağılışı.

Figure 2. Distribution of first marriage age according to provinces.

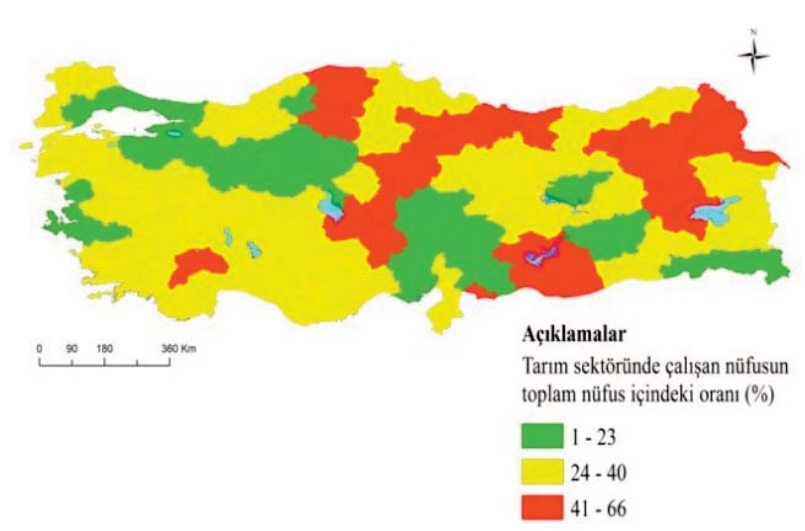

Şekil 3. Tarımsal nüfus oranının illere göre dağılışı.

Figure 3. Distribution of agricultural population ratio according to provinces.

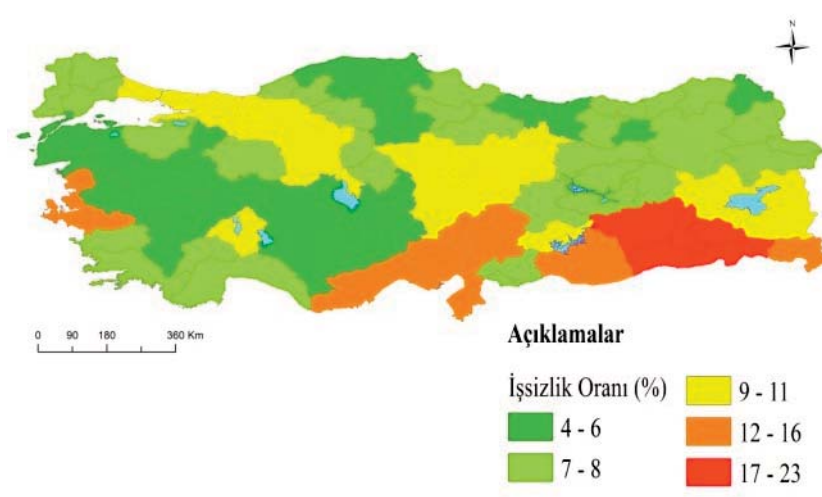

Şekil 4. İşsizlik oranının illere göre dağılışı.

Figure 4. Distribution of unemployment ratio according to provinces.

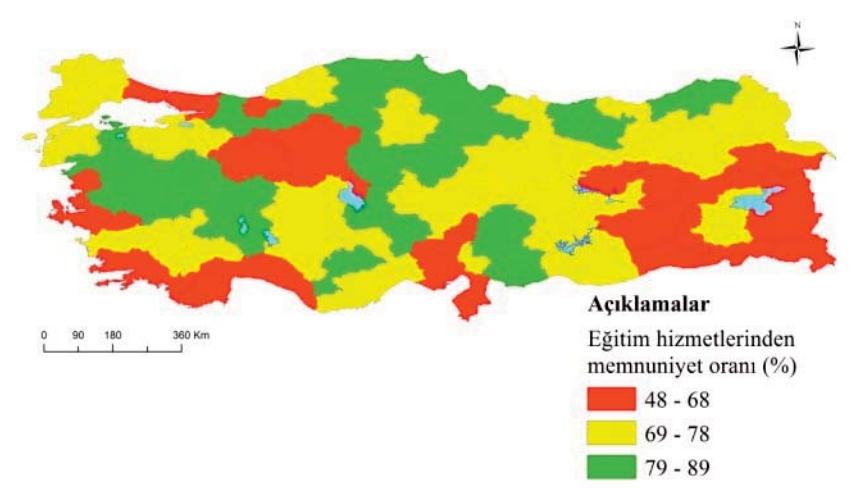

Şekil 5. Eğitim hizmetlerinden memnuniyet oranının illere göre dağılışı. Figure 5. Distribution of satisfaction rate of educational services according to provinces.

\subsection{Mutluluk oranlarının bölgeler düzeyinde dağılışı}

Marmara Bölgesi içinde yer alan illerin mutluluk düzeyleri incelendiğinde Kırklareli, Edirne ve Tekirdağ illeri mutluluk oranlarının en düşük olduğu alanlar olması, bölgenin mutluluk profilinin en dikkat çekici unsurudur. Çalışmada kullanılan değişkenler dikkate alındığında bu üç ilde boşanma hızları ve intihar oranları bölge ortalamasının üzerindedir. Bölgede mutluluk düzeyi yüksek olan tek il ise Sakarya'dır. Sakarya ilinde ise dikkat çeken en önemli unsur kamu hizmetlerinden memnuniyet oranının bölge ortalamasının oldukça üzerinde olmasidır.

Ege Bölgesinde mutluluk oranlarının dağılışında bölgenin kuzey ve güneyinde birbirinden tamamen farklı bir durum dikkat çeker. Mutluluk oranları bölgenin kuzey ve doğusunda yer alan Kütahya, Uşak ve Afyon'da yüksek iken, güneydeki Aydın ve Muğla illerinde oldukça düşüktür. Mutluluk oranlarının düşük olduğu alanlarda ortalama ilk evlenme yaşı ve intihar hızı bölge ortalamasının üzerindedir. Bununla birlikte kamu hizmetlerinden memnuniyet düzeyinin de oldukça düşük olduğu görülmektedir.

Karadeniz Bölgesinin özellikle doğusunda mutluluk oranlarının dağılışında belirgin bir farklılaşma bulunmamaktadır. Bu alanda mutluluk oranı yüksek olan tek il Bayburt'tur. İlde en fazla dikkat çeken unsur tarımsal faaliyetlerde istihdam olan nüfus oranının oldukça yüksek (\% 50) olmasıdır. Bununla birlikte ilin ortalama intihar hızı da bölge ortalamasının altındadır. Mutluluk oranlarındaki farklılaşmanın en belirgin olduğu alan Bat Ka- 
radeniz'dir. Bu alanda Düzce ve Bolu en mutlu iller arasında yer alırken bu illere komşu olan Karabük ve Zonguldak bölgenin mutluluk oranları en düşük olan illerindendir. Çalışmada kullanılan değişkenler kapsamında bir değerlendirme yapılacak olursa Düzce ve Bolu illeri, bu bölgede işsizlik oranlarının en yüksek olduğu illerdir. Bununla birlikte boşanma hızları açısından da değerler bölge ortalamasının oldukça üzerindedir. Mutluluk oranlarının en düşük olduğu illerden olan Zonguldak ve Bartın'da ise en fazla dikkat çeken değerler kamu hizmetlerinden memnuniyet düzeyi ile ilişkili olanlardır. Özellikle Zonguldak'ta adli hizmetler ve ulaştırma hizmetlerinden memnuniyet düzeyi bölge ortalamasının oldukça altındadır. Bir diğer dikkat çekici unsur intihar hızları ile ilgilidir. Bölge genelinde ortalama intihar hızı \%o 3.8 iken Zonguldak'ta \%o 5.13, Bartın'da \%o 6.89 'dur.

Bu alanda mutluluk oranlarının mekânsal dağılış özellikleri konusunda diğer bir farklılaşma birbirine komşu olan Sinop ve Samsun illerinde görülür. Sinop, Türkiye'nin en mutlu ili iken, Samsun mutluluk oranlarının en düşük olduğu illerdendir. Her iki ilde de kamu hizmetlerinden memnuniyet oranı oldukça yüksek olmasına rağmen Sinop özellikle yaş bağımlılık oranı bakımından bölge illerinden ayrılmaktadır.

İç Anadolu Bölgesi ortalama mutluluk oranlarının en yüksek olduğu, Türkiye'nin en mutlu bölgesidir. Bölgede Ankara dışındaki tüm iller mutlu veya orta düzeyde mutlu kategorisinde yer almaktadır. Ankara'yı bölgede yer alan illere göre farklı kılan özellik, gelir seviyesinin en yüksek buna rağmen mutluluk oranlarının en düşük olduğu il olmasıdır. Diğer değişkenlerden olan kamu hizmetlerinden memnuniyet oranlarının bölge ortalamasının altında olduğu görülür. Örneğin sağıık hizmetlerinden memnuniyet oranı bölge genelinde \% 81,2 iken Ankara'da $\%$ 68,1, eğitim hizmetlerinden memnuniyet oranının bölge ortalaması \% 75,7 iken Ankara'da \% 58,0 'dır. Ankara aynı zamanda işgücünün sektörel dağılımı açısından da bölgede bulunan diğer illerden oldukça farklıdır. Tarım sektöründe çalışan nüfusun oranı \% 4,8 iken hizmet sektöründe çalışanların oranı bölge ortalamasının oldukça üstündedir. Ayrıca bölgede yer alan boşanma hızı en yüksek il durumundadır. Bahsedilen değişkenlere ilişkin bu değerler Türkiye genelinde mutluluğu etkileyen unsurlar ile benzerlik gösterir. Ankara iline komşu olan Çankırı, Kırıkkale, Kırşehir ve Aksaray illeri ise mutluluk düzeyleri en yüksek olan illerdir. Kırşehir dışında bahsedilen illerde kişi başına düşen GSYiH bölge ortalamasının altında ve bu dört ilde kamu hizmetlerinden memnuniyet oranları bölge ortalamasının oldukça üzerindedir. Aynı zamanda bu illerde tarım sektöründe çalışan nüfusun oranı yüksek, intihar oranları da bölge ortalamasının altındadır. Bu durum Türkiye'de mutluluğu etkilediği belirlenmiş olan unsurlar ile paralellik göstermektedir.

Akdeniz Bölgesi'nde yer alan illerden Kahramanmaraş ve Isparta illeri mutlu, Antalya, Mersin, Adana, Osmaniye ve Hatay illeri ise mutsuz olarak belirlenmiştir. Mutlu iller olan Isparta ve Kahramanmaraş'ta kişi başına düşen GSYiH ve boşanma hızları bölge ortalamasının altında buna karşın kamu hizmetlerinden memnuniyet oranı oldukça yüksektir. Türkiye genelinde mutluluk ile ilişkisi araştrılmış ve etkili olduğu belirlenmiş bu değişkenler Akdeniz bölgesi içinde geçerlidir. Mutluluk oranlarını düşük illerde ise özellikle kaba intihar hızlarının yüksektir.

Güneydoğu Anadolu Bölgesi mutluluk oranlarının en düşük olduğu bölge durumundadır. Bölgede bulunan illerin tamamı orta düzeyde mutlu ve mutsuz iller kategorilerinde yer alır. Mutluluk düzeylerinin en düşük olduğu iller Diyarbakır, Batman ve Mardin'dir. Bu illerde özellikle eğitim ve asayiş hizmetlerinden memnuniyet oranı oldukça düşük, işsizlik oranları hem bölge hem de Türkiye genelinde en yüksek olan illerdir. Bununla birlikte tarım sektöründe çalışanların oranı da bölge ortalamasının altındadır. Asayiş hizmetlerinin yetersiz oluşu ve işsizlik oranlarının çok yüksek oluşu bölgedeki mutluluk profilini etkileyen en önemli değişkenler olarak dikkat çeker.

Doğu Anadolu Bölgesinde mutluluk oranlarının mekânsal dağılışında belirgin bir farklılaşma söz konusudur. Mutluluk düzeyleri yüksek olan iller bölgenin güneyinde yer alan Siirt, Şırnak ve Hakkari'dir. Bu illerin Türkiye'nin en mutlu alanları olması dikkat çekicidir. Bölgede mutluluk oranlarının yüksek olduğu illerde kişi başına düşen GSYiH oranları ve boşanma hızları oldukça düşük, işsizlik oranlarının ise Türkiye'de en yüksek olduğu alanlardandır. Mutsuz illerin profilleri incelenecek olursa en fazla dikkat çeken unsur Tunceli, Elazığ ve Malatya illerinde boşanma oranlarının bölge ortalamasının oldukça üzerinde olmasıdır. Bu üç il arasında özellikle Tunceli farklı bir yere sahiptir. Ülke geneli için belirlenmiş, mutluluk oranlarının düşmesine neden olan unsurların büyük bölümü bu il için geçerli durumdadır.

\section{Tartışma ve sonuç}

TÜik 2013 yılı yaşam memnuniyeti anketi sonuçlarına göre bireylerin mutluluk kaynağı temelde "aile"dir. Ancak burada kullanılan aile ifadesi tüm aile üyelerini kapsamaktadır. Mutluluk kaynağı olarak aile üyeleri ayrı ayrı değerlendirildiğinde payları oldukça düşüktür. Yani ailenin en önemli mutluluk kaynağı olmasının koşulunun tüm aile üyelerinin bir arada bulunması olduğu söylenilebilir. Aileden sonra toplumsal mutluluğun kaynağı sağlık, sevgi, başarı, para ve bir iş sahibi olmaktır. Mutluluk kaynağı olarak aile dışında ülke genelindeki belirgin farkIılıklardan biri kadınların erkeklere oranla daha mutlu olmasıdır. Frey ve Stutzer (2002) ve Gerdtham ve Johannes (2001) tarafindan yapılan çalışmada da benzer sonuçlar elde edilmiştir. Burada dikkat çeken olumsuzluk bireyin mutlu olmasına neden olan unsurlar arasında "kendisi"nin payının yalnızca \% 2,5 olmasıdır. Toplumsal mutluluğun sürekliliği açısından bu durum endişe vericidir. Çünkü bireyin ekonomik veya sosyal yaşantsında yaşanacak herhangi bir olumsuz durumda mutsuz duruma düşebilecektir. Bu ise toplumdaki mutluluk halinin ne kadar hassas ve kırılgan olduğunu gösterir.

Demografik göstergeler açısından en fazla dikkat çeken durum hem erkek hem de kadın nüfus için ilk evlenme yaşıdır. Her iki cinsiyet grubu içinde ilk evlenme yaşı ve mutluluk düzeyi arasında negatif bir ilişki bulunduğu tespit edilmiştir. Bülbül ve Giray (2011)'da evli olan genç kadınların orta-üst mutluluk düzeylerinde yer aldığını ifade eder. Türkiye'de ilk evlenme yaşı düşük olan bireyler genellikle eğitim seviyesi toplumun geneline göre düşük, iş hayatnna daha az dahil olan dolayısıyla gelir seviyesi daha düşük olan nüfusu teşkil eder. Bu grup aynı zamanda görece yoksul olan bireylerden oluşur. Todaro ve Smith (2012), yoksul bireylerin olumlu herhangi bir durumdan daha fazla faydaya sahip olma potansiyeli olduğunu ifade eder. Başka bir deyişle gelir seviyesi düşük grupların mutluluk normları daha düşüktür. İlk evlenme yaşı ve mutluluk düzeyi arasında belirlenmiş olan ilişkiyi bu şekilde açıklamak mümkündür. 
Evliliğin mutluluğu arttırıcı bir unsur olduğu birçok çalışmada belirtilmektedir (Blanchflower ve Oswald 2000; Heliwell, 2003). Bu çalışmada da boşanma oranlarının düşük olduğu illerin diğerlerine oranla daha mutlu olduğu görülmüştür. Boşanma oranlarının en az olduğu yerler özellikle Doğu ve Güneydoğu Anadolu Bölgesi sınırları içinde yer alan illerdir. Bu iller aynı zamanda ilk evlenme yaşının da en düşük olduğu illerdir. Mutluluğu olumlu yönde etkileyen iki unsurun aynı illerde yoğunlaşması da elde edilen sonuçların tutarlılığı açısından önem taşır. İntihar olayları sosyal çalışmaların pek çoğunda dikkate alınan bir unsurdur. Çünkü doğrudan toplumsal psikoloji ile ilişkilidir. Mutsuz toplumlarda intihar hızının yüksek olması beklenen bir durumdur. Bray ve Gunnell (2006) tarafindan yapılan araştırmada intihar oranlarındaki farklılaşmanın mutluluğu arttırıcı veya azaltıcı etki yarattı̆ını ifade eder. Bu çalışmada da intihar oranı mutluluğu yansıtan ve etkileyen bir unsur olarak dikkat çeker. Başka bir deyişle Türkiye'de yaşanan intihar olayları mutluluk ile ilişkili bir durumdur.

Kamu hizmetlerinden memnuniyet düzeyi mutluluk üzerindeki en belirleyici unsurlardır. Özellikle gelişmekte olan toplumlarda devlet tarafindan uygulanan politika ve uygulamalar büyük önem arz eder. Sosyal güvenlik, sağlık, eğitim, ulaşım, asayiş ve adli hizmetlerdeki iyileşmelerin topluma mutluluk olarak yansıdığı söylenebilir. Frey ve Stutzer (2002) pek çok ülkede kamu hizmetleri ile mutluluk arasında kuvvetli bir ilişki olduğunu ifade eder.

Ekonomik değişkenler içinde en fazla değerlendirilen unsur gelirle ilişkili olanlardır. Ancak gelir arttıkça mutluluk düzeyinin artacağı görüşü günümüzde yeterince kabul görmemektedir. Easterlin (1995), gelir ve mutluluk ilişkisini incelediği çalışmasında gelir seviyesi yüksek olan ülkelerin diğerlerine göre daha mutlu olduğunu ancak ülke genelinde ortalama gelirde yaşanan artışın subjektif refahın normlarında da değişiklik yarattı̆ını ifade eder. Başka bir deyişle ülkenin gelir seviyesi arttıķa genel olarak mutluluk düzeyinin arttğını söylemek mümkündür ancak gelirdeki artışın subjektif anlamda mutluluğu arttığı söylenemez. Türkiye'de illere göre kişi başına düşen GSYiH arttkça mutluluk oranlarının azaldığı görülmüştür. Ekonomik göstergeler açısından en belirgin ilişki işsizlik ve mutluluk düzeyleri arasında test edilmiştir. Bu iki değişken arasında negatif bir ilişki bulunmaktadır. Bir diğer ifadeyle Türkiye'de işsizlik mutluluk oranlarını olumsuz yönde etkilemektedir. Clark (2003) ve Clark ve Oswald (1994)'ın çalışmalarında benzer sonuçlar elde edilmiştir. Di Tella ve MacCulloch (2006) tarafindan yapılan araştırmadada işsizlik arttkça refahın düştüğü ifade edilmektedir.

Türkiye'nin mutluluk profili incelendiğinde çalışılan ekonomik sektörün mutluluk üzerinde belirleyici olduğu görülmüştür. Ancak tarımda çalışan nüfusun fazla olduğu illerde mutluluk oranının daha fazla oluşu beklenmeyen bir öngörüdür. Tarım sektöründe çalışan nüfus hem maddi hem de maddi olmayan yoksunluklar açısından dezavantajlı bir grubu temsil etmektedir. Yoksunlukların fazla oluşu aslında mutsuzluğu beraberinde getirmelidir. Ancak tam tersi bir durum söz konusudur. Bu durumu subjektif refah kıstaslarının mutluluk düzeyleri üzerinde belirleyici bir etki yaratması ile açıklamak mümkündür. Tarımsal nüfus görece daha yoksul olduğundan mutluluk kıstasları da yoksul olmayan veya kentte yaşayan nüfusa göre daha düşük olmaktadır. Bu nedenle tarımda çalışan nüfusun fazla olduğu illerde mutluluk düzeyleri daha yüksek olarak belirlenmiştir.
Mutluluk çok boyutlu bir kavramdır. Etkilediği ve etkilendiği pek çok değişken mevcuttur. Bu nedenle mutsuz illerde birden fazla olumsuz durumun bir arada bulunması muhtemeldir. İtici unsurların yoğun olduğu alanlardan bireylerin göç etmesi beklenir. Bu anlamda mutluluk oranı düşük illerin daha fazla göç vermesi öngörülür. Çalışmanın bulguları bu bakımdan tutarlıdır. Mutsuz illerin net göç hızları mutlu illere göre daha yüksektir. Ancak mutluluk ve göç ilişkisini araştıran küçük ölçekli ve ayrıntılı çalışmaların yapılması gerekmektedir.

Yaş ve yaş bağımlılık oranı toplumsal araştırmalarda değerlendirilen en önemli değişkenlerdendir. Çünkü yaşlı ve çocuklar toplum içindeki en dezavantajlı gruplardan olmaları nedeniyle özellikle sosyal politikalarda ayrıcalıklı bir grup oluşturur. Mutluluk ve yaş ilişkisini inceleyen pek çok çalışma bulunmaktadır. Bu çalışmalarda yaş ve mutluluk konusundaki değerlendirmeler U-Şekilli Mutluluk Teorisi dikkate alınarak yapılmaktadır. Bu teoriye göre yirmi yaş altt ve elli yaş üstünde yer alan nüfusun mutluluk oranları toplumun geneline oranla yüksektir. Teoriye göre çocuklar toplumun geneline göre daha kolay mutlu olabilme potansiyeline sahip olup, yaşlı nüfus ise her ne kadar hastalıklarla mücadele ediyor olsalar da bu durum onlar için kabul edilebilir olarak tanımlanmaktadır. Bu nedenle bağımlı nüfusun mutluluk oranları toplumun geneline göre daha yüksek olmaktadır (Blanchflower ve Oswald, 2006; Villarroel, vd., 2012). Bu çalışmada da yapılan diğer araştırmalarla benzer sonuçlar elde edilmiştir. Buna göre Türkiye'de yaş bağımlılığının fazla olduğu iller daha mutludur.

Mutluluk bir refah göstergesi olsa da özgürlük ve adalet gibi unsurlarla birlikte gelişmediği sürece herhangi bir değer teşkil etmez. Türkiye'de mutluluğun dağılışı ve nedenlerine bakılacak olursa mutluluğa neden olan etmenlerin aslında insanın hayatını devam ettirebilmesi için ihtiyaç duyduğu temel unsurlar olduğu görülür. Türkiye'de mutlulukla ilişkili pek çok unsur aslında dolaylı olarak gelirle ilişkilidir. Tarımda çalışan nüfusun gelir seviyesi görece düşük, yoksulluk oranı görece yüksektir. Bu kesim genellikle kır nüfusunu oluşturur. Kır nüfusunun eğitim düzeyi ve ortalama evlenme yaşı kentlere oranla daha düşüktür. Bu alanlar aynı zamanda daha mutlu illere karşılık gelmektedir. Yani gelir doğrudan bir belirleyici olmamakla birlikte gelir seviyesine göre şekillenen yaşam ve yaşam kalitesi normları mutluluk üzerinde belirleyicidir. Bu çalışmada Türkiye'de mutluluğun dağılışı ve bu dağılışta etkili unsurlar belirlenmiş, Türkiye'nin mutluluk profili oluşturulmuştur. Elde edilen sonuçlar sosyal politikaların planlanması sürecinde ve kalkınmaya yönelik uygulamalarda dikkate alındığı taktirde yol gösterici olacaktir.

\section{Kaynakça}

Ardalan, A., Mazaheri, M., Vanrooyen, M., Mowafi, H., Nedjat, S., Holakouie, N. (2011). "Post-Disaster Quality Among Older Survivors 5 Years After Bam Earthquake Implications for Recovery Policy", Ageing and Society, 31, 179-196.

Blanchflower, D.G., Oswald, A. J. (2006). "Is Well-being U-Shaped Over the Life Cycle?", Social Science and Medicine 66, 1733-1749.

Blanchflower, D. G.; Oswald, A. (2000)." Well-Being Over Time in Britain and the USA", NBER Working Paper No. 6102. Cambridge, Mass: National Bureau of Economic Research. Bray, I., Gunnell, D. (2006). "Suicide Rates, Life Satisfaction and 
Happiness as Markers For Population Mental Health". Social Psychiatry and Psychiatric Epidemiology 41, 333-337.

Brereton, F., Clinch, J. P., Ferreira, S. (2008). "Happiness, Geography and The Environment", Ecological Economics, 65, pp.386-396.

Bülbül, Ş., Giray, S. (2011). "Sosyodemografik Özellikler ile Mutluluk Algısı Arasındaki İlişkinin Yapısal Analizi”, Ege Akademik Bakış, Cilt: 11, s. 113-123.

Calvo, R., Arcaya, M., Baum, C. F., Lowe, S. R., Waters, M. C. (2014). "Happily Ever After? Pre-And-Post Disaster Determinants of Happiness Among Survivors Of Hurricane Katrina". Journal Of Happiness Studies, 1-16.

Cheung, H. Y., Chan, A. W. (2011). "The Relationship of Competitiveness Motive on People's Happiness Through Education". International Journal Of Intercultural Relations, 35(2), 179-185.

Clark, A. (2003). "Unemployment as a Social Norm: Psychological Evidence From Panel Data", Journal Of Labor Economics, 21, 324-351.

Clark, A., Oswald, A., (1994). "Unhappiness and Unemployment", Economic Journal, 104, 648-659.

Di Tella, R., MacCulloch, R. J., (2006). "Some Uses of Happiness Data in Economics", Journal of Economic Perspectives, 20(1): 25-46.

Easterlin, R. A., (1995). "Will Raising the Incomes of all Increase the Happiness of all?", Journal of Economic Behavior and Organization, Vol. 27, pp. 35-47.

Easterlin, R. A. (2001). "Income and happiness: Towards a unified theory." The Economic Journal 111 (473), 465-484.

Frey, B., Stutzer, A. (2002). "What Can Economists Learn from Happiness Research", Journal of Economic Literature, 40(2), 402-435.

Gerdtham, U. G., Johannes, M. (2001). “The Relationship Between Happiness, Health and Socio-Economic Factors: Results Based on Swedish Micro Data", Journal of Socio-Economics, 20, 553-557.

Helliwell, J. F., (2003). "How's life? Combining individual and national variables to explain subjective well-being". Economic Modelling, 20(2): 331-360.

Jazairy I., Alamgir, M., Panuccio, T., (1992). The State of World Rural Poverty: An Inquiry Into Its Causes and Consequences, Intermediate Technology Publications, London.

Kahneman, D., Tversky, A. (2003). "Experienced Utility and Objective Happiness: A Moment Based Approach", The Psychology of Economic Decisions, 1, 187-208.

Layard, R. (2005). Happiness: Lessons from a New Science, Penguin Books, London.

Le Bon, G. (2014). Kitlelerin Psikolojisi, Tutku Yayınevi, ISBN:978-605-4756-82-7, Ankara.

Liltsi, P., Michailidis, A., Partalidou, M. (2014). "Mapping Perceived Happiness Alongside the Rural-Urban Continuum", Procedia, 9, 288-301.

Lucas, R. E., Gohm, C. L. (2000). "Age and Sex Differences in Subjective Well-being Across Cultures". Culture and subjective wellbeing, 3, 291-317.

McGillivray, M., Clarke, M., eds.(2006). Understanding Human Well-Being. Tokyo: United Nations University Press.

Ravallion, M.; Wodon,Q. (1997). Poor Areas or Only Poor People?, Policy Research Working Paper 1798, The World Bank, Washington D.C.

Rehdanz, K., Maddison, D. (2005), "Climate and Happiness",
Ecological Economics, 52, pp. 111-125.

Shapiro, J. M. (2006). "Smart Cities: Qualirty of life, productivity and the Growth effects of human capital", Review of Economics and Statistics, 88(2), 324-335.

Sen, A. (1987), The Standard of Living, Cambridge University Press, New York.

T.C. Kalkınma Bakanlığı, (2013). Onuncu Kalkınma Planı 20142018, Ankara.

Todaro, M. P., Smith,S. (2012). Economic Development, 11th Edition, ISBN: 978-0-13-801388-12, Pearson, USA.

TÜiK, (2014). ADNKS, Yerleşim Yerlerine Göre Verdiği ve Aldığı Göç, Erişim Tarihi: 15.04.2015.

TÜik, (2014). ADNKS, Toplam Yaş Bağımlılık Oranları, Erişim Tarihi: 15.04.2015.

TÜiK, (2014), ADNKS, Boşanma Sayıları, Erişim Tarihi: 15.04.2015.

TÜiK, (2014), ADNKS, Ortalama Hanehalkı Büyüklüğü, Erişim Tarihi: 15.04.2015.

TÜiK, (2014), ADNKS, Kaba Intihar Hızı, Erişim Tarihi: 15.04.2015.

TÜiK, (2014), ADNKS Erkek Ve Kadın Nüfus İçin İlk Evlenme Yaşı, Erişim Tarihi: 15.04.2015.

TÜIK, (2013), ADNKS, Bitirilen Eğitim Düzeyi, Erişim Tarihi: 15.04.2015.

TÜiK, (2013), ADNKS İşsizlik Oranları, Erişim Tarihi: 15.04.2015.

TÜik, (2013). Yaşam Memnuniyeti Anketi Sonuçları, İllere Göre Mutluluk Oranları, Erişim Tarihi: 15.04.2015.

TÜik, (2013). Yaşam Memnuniyeti Anketi Sonuçları, illere Göre Mutluluk Kaynağı, Erişim Tarihi: 15.04.2015.

TÜik, (2013). Yaşam Memnuniyeti Anketi Sonuçları, Kamu Kurum Ve Kuruluşlarının Hizmetlerinden Memnuniyet Oranı, Erişim Tarihi: 15.04.2015.

TÜiK, (2011). Çalışan Nüfusun Ekonomik Sektörlere Dağıışı, Erişim Tarihi: 15.04.2015.

TÜiK, (2001). Kişi Başına Düşen GSYiH, Erişim Tarihi: 15.04.2015

UN, (2005). Handbook on Poverty Statistics: Concepts, Methods and Policy Use, United Nations Statistics Division, New York.

Van Praag, B., Baarsma, B. (2005). "Using Happiness Surveys to Value Intangbiles: The Case of Airport Noise", Economic Journal, 2, pp. 111-125.

Villarroel, P. V., Atenas, K. C., Pavez, p., Lillo, S., Diaz, N., Lopez, W. (2012). "Money, Age and Happiness: Association of Subjective Wellbeing with Socio-Demographic Variables, Revista Latinoamericana de Psicologia. Vol. 44/2, pp. 155-163.

Welsch, H, (2006). "Environment and Happiness: Valuation of Air Pollution Using Life Satisfaction Data", Ecological Economics, 58, pp. 801-813.

Welsch, H. (2002). "Preferences Over Prosperity and Pollution: Environmental Valuation Based on Happiness Survey, Kyklos, 55 (4), pp. 473-494. 